Marquette University

e-Publications@Marquette

Finance Faculty Research and Publications

Finance, Department of

$10-1-2001$

\title{
An Empirical Examination of Traditional Neighborhood Development
}

Charles C. Tu

California State University - Fullerton

Mark Eppli

Marquette University, mark.eppli@marquette.edu

Accepted version. Real Estate Economics, Vol. 29, No. 3 (Fall 2001): 485-501. DOI. (C) 2001 Blackwell Publishing. Used with permission.

Mark Eppli was affiliated with George Washington University at time of publication. 


\title{
An Empirical Examination of Traditional Neighborhood Development
}

\author{
By Charles C. Tu* and Mark J. Eppli*
}

This study analyzes the impact of the new urbanism on single-family home prices. Specifically, we explore the price differential that homebuyers pay for houses in new urbanist developments relative to houses in conventional suburban developments. Using data on over 5,000 single-family home sales from 1994 to 1997 in three different neighborhoods, hedonic regression results reveal that consumers pay more for homes in new urbanist communities than those in conventional suburban developments. Further analyses indicate that the price premium is not attributable to differences in improvement age and other housing characteristics.

The new urbanism and other socially conscious movements in architecture and planning (e.g., smart growth and sustainable communities) have recently taken center stage in political and environmental discussions. While intense debate about the societal benefits and validity of the new urbanism is being carried out among practitioners and academics, the number of new urbanist communities has increased many fold. ${ }^{2}$ Despite the growth in the number of traditional neighborhood developments (TNDs), ${ }^{3}$ little research has been completed that examines the market acceptance of the new urbanism. ${ }^{4}$

This research explores the value of the new urbanism from a housing market perspective. Using three of the most complete, year-round new urbanist communities in the United State we examine: (1) whether consumers pay the same price for single-family homes in new urbanist developments and for comparable single-family homes in conventional developments, and (2) if there is a price differential, whether it is attributable to new urbanist features available in TNDs or to differences in other housing attributes between the two types of developments. The results of various hedonic analyses reveal that consumers consistently pay more to live in new urbanist communities and that these findings are robust across functional form and model specification. Additionally, a decomposition analysis reveals that the price premium is likely to be attributable to new urbanist features rather than differences in housing characteristics such as size, age, and quality.

The remainder of the paper is organized as follows. The next section briefly describes the methodology and data employed in this study. Section three presents the empirical results of the 
hedonic analysis of three new urbanist communities. Additional analyses are conducted to verify that any price differentials identified in the hedonic model are not caused by misspecification. Section four examines the price differential between TNDs and conventional developments by applying a decomposition technique. The last section concludes the paper by summarizing the findings.

\section{Methodology and Data}

This study uses the hedonic price model to isolate the effect of the new urbanism from other single-family structure, quality, and location characteristics. In the hedonic model, housing is viewed as a bundle of attributes such as site, improvement, location, and market characteristics. As a result, housing value is determined by the type and quantity of attributes embodied in a house and the implicit price of each attribute, such that

$P=f\left(x_{i}, \beta_{i}\right)=\sum \beta_{i} \cdot x_{i}+\varepsilon_{i}$,

where

$P$ = housing value

$x_{i}=$ quantity of the $i$ th housing attribute

$\beta_{i}=$ price of the $i$ th housing attribute, and

$\varepsilon=$ error term

The hedonic price model has been well developed and extensively used in housing market research; however, several empirical issues remain unresolved, including functional form, variable selection, and market delineation. ${ }^{5}$ Since no single form of the hedonic model is perfect, we estimate a series of functional forms including the linear, semi-log, and the Box-Cox (1964) transformation to evaluate the robustness of estimation results. To avoid omitted variable bias we use as many housing characteristics as are consistently provided by the data sources while testing for collinearity. To prevent market aggregation bias, we draw data from a narrowly defined geographical area. ${ }^{6}$ This strategy also helps us control for locational factors such as school district and tax district.

To properly assess the effect of the new urbanism, it is essential to identify a group of communities that reflect the characteristics of the new urbanism and meet hedonic requirements. Furthermore, to estimate the price differential between TNDs and conventional communities, the types of housing units in the control group must be similar to TND properties in terms of general housing attributes but different in terms of the new urbanist features. We identify three market 
areas that include a new urbanist development, have comparable quality housing in the surrounding area, and provide a sufficient number of single-family sale transactions to complete a hedonic analysis: Kentlands in the Washington, D.C. metropolitan area; Laguna West near Sacramento, California; and Southern Village in Chapel Hill, North Carolina. ${ }^{7}$ A discussion of the selection process is presented in the Appendix.

Sale transaction data for single-family homes in the three market areas were collected for the period 1994 to 1997. The primary data source of the study is First American Real Estate Solutions (FARES, formerly known as Experian). Each transaction record contains property location, assessed value, sale transaction price, and numerous other site and improvement attributes. An important housing attribute not provided by FARES is construction quality, which is collected separately from each municipality. Table 1 describes the variables used in the hedonic analysis.

The hedonic price model requires a set of market clearing prices to estimate the implicit price of each housing attribute. To ensure that the data reflect the housing market clearing conditions, highly unusual sale transactions are systematically eliminated using data parsing criteria. ${ }^{8}$ The first screening criterion is based on housing characteristics of each property. Removing transactions of houses with extreme characteristics ensures a pool of homogeneous transactions. For example, transactions with large tracts of land can be used for nonresidential purposes (i.e., a mini-farm, a small business, a residential development, etc.). To prevent transactions with unusual housing attributes from unduly affecting parameter estimates, transactions that have a lot size greater than two acres, have more than five bathrooms, or are older than 80 years are excluded. The second criterion is a sale-price-to-assessed-value ratio. Transactions with a sale price that are $60 \%$ less than or $60 \%$ greater than the assessed value are deleted from the data set. Removal of these outlying observations prevents coding errors, non-arms-length transactions, and properties with unique characteristics from unduly influencing the pricing model. Table 2 presents the summary statistics of the data sets used in the hedonic analysis.

Table 3 stratifies the summary statistics by type of residential development. The mean price of homes in TNDs is substantially higher than those in conventional suburban developments. However, these price differentials may be caused by differences in housing attributes rather than new urbanist features. To isolate the effect of the new urbanism from other housing attributes, we apply the hedonic price model which estimates the implicit price of each housing attribute including the new urbanism. 


\section{Empirical Results of Hedonic Price Model}

Table 4 presents the results of three semi-log form hedonic models using 20 to 22 housing characteristics to estimate the impact of the new urbanism on home prices. ${ }^{9}$ Explanatory power across the communities ranges from $83 \%$ to $87 \%$.

With minor exceptions, parameter estimates of important site and improvement characteristics maintain expected signs and are significant.

To measure the price differential consumers pay between housing in new urbanist and conventional developments, we focus on the parameter estimate of the TND variable. This binary variable has a value of one if the property is located in a new urbanist community and zero otherwise. The TND coefficient reflects the price differential between TND properties and surrounding properties after controlling for site, interior, exterior, quality, and market characteristics of the houses. ${ }^{10}$ The TND parameter estimate is positive and significant (at the $1 \%$ level) across all communities. The results indicate that consumers pay a higher price for housing in TNDs over comparable housing in surrounding conventional developments.

The price premium for new urbanist housing exists across geographical areas; however, its magnitude is diverse. To live in the new urbanist community, homebuyers pay a premium of approximately $14.9 \%$ of property value in Kentlands, $4.1 \%$ in Laguna West, and $10.3 \%$ in Southern Village. ${ }^{11}$ The range of the price premiums may be a result of consumer preference differences across geographical areas. Alternatively, the variance may be attributable to the degree that new urbanism principles are implemented in each community. To ensure that the identified price differential is not caused by the choice of functional form, additional estimations are completed for each market area using the linear and the Box-Cox maximum likelihood functional forms. In all cases the TND parameter estimate remains significant at the $1 \%$ level. $^{12}$

Since the three new urbanist communities were developed in the 1990s, the mean housing age in TNDs is lower than the mean age in the surrounding area, which could result in

biased estimates. ${ }^{13}$ We therefore compare homes in TNDs with newer homes in the surrounding areas. Table 5 shows the price differentials for samples stratified by improvement age. For all market areas, the TND parameter estimates are positive, significant at the $1 \%$ level, and stable across age stratifications.

Another way that age may affect the price differential is through community age (rather than improvement age). Community age bias can occur if the age of the TND generates a premium and not the new urbanist features. To address this potential bias we conduct a stacked regression analysis by pooling all three data sets and using the mean housing age (MAGE) as a 
proxy for community age: ${ }^{14}$

$P=\sum_{k} \beta_{i} \cdot x_{i}+\sum_{l} \beta_{i} \cdot x_{i}+\sum_{s} \beta_{i} \cdot x_{i}+\theta \cdot M A G E+\epsilon_{i}$

where the subscripts $k, I$, and $s$ refer to market areas of Kentlands, Laguna West, and Southern Village; $\theta$ is the coefficient of community age; and $x_{i}$ and $\beta_{i}$ are similar to those in the hedonic models.

Other independent variables $\left(x_{i}\right)$ in the stacked regression include those common to each of the three community analyses and two binary variables representing the state where a TND is located (with Laguna West market area being the reference group). If the price differential is attributable to community age, the parameter estimate of MAGE will be negative and significant with the TND variable becoming smaller in magnitude and less significant.

Table 6 reports the estimation results of two separate stacked regression analyses.

Specification 1 presents the results of an analysis using 19 housing attributes. ${ }^{15}$ Specification 2 maintains the same 19 variables plus 30 interactive terms, 16 for Kentlands and 14 for Southern Village. The interactive terms in Specification 2 allow the housing attributes to be priced differently for each market area. Both models reveal a negative and significant (at the $1 \%$ level) parameter estimate for the MAGE variable. However, the TND variable remains positive, significant (at the 1\% level), and similar in magnitude to results presented in Table 4, suggesting that a price premium for new urbanist features exists after controlling for community age.

The results of the improvement age stratified regressions and the stacked regressions indicate that the price premiums identified in the hedonic models are not attributable to age differences in the housing units or age differences in the communities when comparing TNDs to the surrounding conventional developments.

\section{Decomposition Analysis}

An alternative approach to conducting a constant quality comparison of housing value is the decomposition analysis developed by Goodman and Thibodeau (1998). In this analysis the housing price differential between two submarkets is separated into two components: the characteristic effect, which is caused by the differences in housing attributes available in these two submarkets, and the price effect, which is attributable to the different implicit prices of the housing features.

To perform the decomposition we estimate separate semi-log regressions for submarket $j$ (TND) and submarket $k$ (surrounding area) with $P$ denoting the house price, $x_{i}$ the $i$ th housing characteristic, and $\beta_{i}$ the coefficient in the regression. The ratio of prices in the two submarkets 
are expressed as

$\ln \left(P_{j} / P_{k}\right)=\sum_{i} \beta_{i}^{*} \cdot \Delta x_{i}+\sum_{i} x_{i}^{*} \cdot \Delta \beta_{i}$,

where

$\Delta x_{i}=\left(x_{i j}-x_{i k}\right)$,

$\Delta \beta_{i}=\left(\beta_{i j}-\beta_{i k}\right)$,

$x_{i}^{*}=\left(x_{i j}+x_{i k}\right) / 2, \quad$ and

$\beta_{i}^{*}=\left(\beta_{i j}+\beta_{i k}\right) / 2$.

The first term of the equation, $\Sigma_{i} \beta_{i}^{*} \cdot \Delta x_{i}$, is the housing characteristic effect, which measures the price differential caused by the differences in housing attributes. The price effect, $\Sigma_{i} x_{i}^{*} \cdot \Delta \beta_{i}$, measures the implicit price differential between new urbanist housing and conventional housing after the characteristic differences have been controlled for. If the new urbanist features are valuable, the price effect is expected to be positive and substantial.

Table 7 summarizes the results of the decomposition analysis for the three market areas. The price effect of Kentlands, Laguna West, and Southern Village are all positive, indicating that the value of new urbanist housing is greater than the value of similar housing in the surrounding area. These results confirm the findings of the hedonic analyses: consumers pay a price premium to reside in a TND and this price differential is not attributable to the differences in property attributes.

We also examine the source of the price effect. If the TND price premium is created through community planning and design, we expect that the price effect in the decomposition analysis will be reflected in the value of the lot and that the intercept term or the lot variable will capture the majority of the price effect. Table 8 shows the decomposition of the price effect for each community. For Laguna West and Southern Village, the differences in the intercept terms account for the majority of the price differential. For Kentlands, the impact of lot value is the dominant factor. Both findings are consistent with the expectation that TND community planning and design generate the price premium.

\section{Conclusion}

This study explores the market acceptance of the new urbanism by examining the price differential between single-family houses located in a TND and comparable properties located in surrounding conventional developments. We find that homeowners pay more to reside in a TND and that this premium is statistically significant for each of the three new urbanist communities: 
Kentlands, Laguna West, and Southern Village. To ensure that the price premium is not attributable to misspecification, particularly with respect to improvement age and community age, additional analyses are conducted. Using data stratified by improvement age we find a positive, stable, and significant TND price premium across all age stratifications and communities studied. Using pooled data in a stacked analysis we find that the price differential remains positive and significant after controlling for community age. Finally, results of a decomposition analysis confirm that consumers pay a price premium to reside in a new urbanist community.

\section{Acknowledgements}

We are thankful to Thomas Thibodeau and two anonymous reviewers for their helpful comments. Partial research support has been provided by the O.T. Carr, Jr., Scholarship Fund and the Master of Science in Finance Program Research and Development Fund at The George Washington University.

\section{Notes}

* Department of Finance, California State University, Fullerton, Fullerton, CA, 92834-0000 or ctu@fullerton.edu

** Department of Finance, George Washington University, Washington, DC, 20052-0001or meppli@gwu.edu

1. For further discussion of the principles of the new urbanism, see Bookout (1992), Katz (1994), Langdon (1994), Adler (1995), Fulton (1996), Southworth (1997), Eppli and Tu (1999), and the Congress for the New Urbanism website at http://www.cnu.org. For a critical examination of the new urbanism, see Landecker (1996), Henderson and Moore (1998), and Krieger (1998).

2. According to New Urban News, an independent publication endorsed by the Congress for the New Urbanism, there were fewer than five communities designed with the principles of the new urbanism in the United States in the early 1990s. In September 1998, there were more than 200 new urbanist developments under construction or being planned nationwide (Steuteville 1998).

3. A community designed with the principles of the new urbanism is often called a new urbanist community or a traditional neighborhood development (TND). In this paper we use these terms interchangeably. Conventional development refers to the low-density, auto-oriented development pattern that is commonly seen in suburban areas since the end of World War II. 
4. Tu and Eppli (1999) find that consumers pay a premium to live in Kentlands, a TND, over living in surrounding conventional developments.

5. For discussion on the empirical issues see Follain and Malpezzi (1980) and Linneman (1982).

6. A drawback of narrow market delineation is not using all available information, which may produce imprecise estimates (Follain and Malpezzi 1980). In the analysis, markets are defined by a zip code or a township. With at least 500 sale transactions in each market area, we do not expect that the market delineation is too narrow to provide precise estimates.

7. For a description of the selected communities see Eppli and Tu (1999).

8. In total, less than $10 \%$ of all observations in each of the three market areas were removed using the parsing criteria. However, there is some concern that the screening criteria may introduce bias due to the implicit stratification of the sample by the dependent variable. Therefore, we also estimate the hedonic model with the entire unscreened sample. The effects of data parsing on estimation results are discussed in the empirical results.

9. The models are estimated with ordinary least squares. Heteroskedasticity is detected but the form is unknown. Therefore, the covariance matrix is estimated with the method developed by White (1980).

10. To control for possible neighborhood effects within a market area, we also specify the models adding census tract binary variables. The inclusion of census tracts improves the explanatory power of the models but does not affect the magnitude and significance of the coefficients of TND variables.

11. For interpretation of dummy variables in semi-log form hedonic models, see Halvorsen and Palmquist (1980).

12. To test if the data parsing criteria create bias, hedonic models are also estimated using the universe of data provided by FARES (i.e., without parsing the data). The estimation results have lower explanatory power with $R^{2}$ ranging from $40 \%$ for Laguna West to nearly $80 \%$ for Kentlands. The TND parameter estimates are significant at the $5 \%$ level across the three communities. The magnitude of the TND price differential remains unchanged for Kentlands and Laguna West but becomes larger for Southern Village.

13. Although property age is included in a quadratic form in the hedonic model ( $A G E$ and AGESQUARE), misspecification of the age variable may significantly affect the new urbanism parameter estimate.

14. The mean property age of the TNDs and the mean age of the surrounding 
developments are used in a stacked regression as a proxy for community age. This proxy for community age could not be previously included in the hedonic models because of collinearity with the $T N D$ variable.

15. This specification assumes that the implicit price of the housing attributes is the same across geographic areas. The price differentials among market areas are reflected in the coefficients of state dummy variables.

\section{References}

Adler, J. 1995. Bye-Bye Suburban Dream. Newsweek 15 May: 40-45.

Bookout, L. 1992. Neotraditional Town Planning: A New Vision for the Suburbs? Urban Land January: 20-26.

Box, G. and D. Cox. 1964. An Analysis of Transformation. Journal of The Royal Statistical Society 26: 211-252. Eppli, M. and C. Tu. 1999. Valuing the New Urbanism: The Impact of the New Urbanism on Prices of Single-Family Homes. Urban Land Institute: Washington, DC.

Follain, J. and S. Malpezzi. 1980. Dissecting Housing Value and Rent: Estimates of Hedonic Indexes for Thirty-Nine Large SMSAs. The Urban Institute: Washington, DC.

Fulton, W. 1996. The New Urbanism: Hope or Hype for American Communities? Lincoln Institute of Land Policy: Cambridge, MA.

Goodman, A. and T. Thibodeau. 1998. Housing Market Segmentation. Journal of Housing Economics 7: 121-143.

Hair, J., R. Anderson, R. Tatham, and W. Black. 1995. Multivariate Data Analysis. Fourth edition. Prentice-Hall: Englewood Cliffs, NJ.

Halvorsen, R. and R. Palmquist. 1980. The Interpretation of Dummy Variables in Semilogarithmic Equations. The American Economic Review 70(3): 474-475.

Henderson, R. and A. Moore. 1998. Plan Obsolescence. Reason June: 42-47. Katz, P. 1994. The New Urbanism: Toward and Architecture of Community. McGraw-Hill Inc.: New York, NY.

Krieger, A. 1998. Whose Urbanism? Architecture November: 73-77. Landecker, H. 1996. Is New Urbanism Good for America? Architecture April: 68-77. Langdon, P. 1994. A Better Place to Live. The University of Massachusetts Press: Amherst, MA.

Linneman, P. 1982. Hedonic Prices and Residential Location. Diamond and Tolley, editors. The Economics of Urban Amenities. Academic Press: Orlando, FL.

New Urban News. 1997. Traditional Neighborhood Development Projects in the U.S.

Tu, Eppli 9 
September/October: 10-13.

Southworth, M. 1997. Walkable Suburbs? An Evaluation of Neotraditional Communities at the Urban Edge. Journal of American Planning Association 63(1): 28-44.

Steuteville, R. 1998. Year of Growth for New Urbanism. New Urban News September/October: 1, 3-7.

Tu, C. and M. Eppli. 1999. Valuing the New Urbanism: The Case of Kentlands. Real Estate Economics 27(3): 425-451.

White, H. 1980. A Heteroskedasticity-Consistent Covariance Matrix Estimator and a Direct Test for Heteroskedasticity. Econometrica 48: 817-838. 


\section{Appendix}

\section{Community Selection}

To properly measure the effect of the new urbanism on single-family home prices, it is essential to identify a group of communities that fully reflects the characteristics of TNDs and meets the requirements of the hedonic methodology. Additionally, to determine the price differential between new urbanist and conventional communities, the types of housing units in the control group must be comparable with TND properties in terms of general housing attributes but different in terms of the new urbanist features. This appendix explains the process of selecting new urbanist developments for the empirical analysis.

As of September 1998 more than two hundred TNDs are in the planning stage or under construction in the United States. Using a list of TNDs published by New Urban News, ${ }^{16}$ we first identify 10 new urbanist communities that had at least 150 completed single-family housing units at the end of $1997 .{ }^{17}$ In addition to selecting TNDs based solely on the quantitative needs of the hedonic price model, several communities are excluded for qualitative reasons. Three qualitative factors are used to parse remaining communities as the best examples for the study, including urban redevelopment, municipally funded projects, and resort communities.

New urbanists attempt to recreate the urban environment of a small town through the development of features that restore a sense of community. One of the limitations of studying urban redevelopment TNDs is that the areas surrounding an urban revitalization project may have characteristics similar to those of the new urbanist developments under study. If the area surrounding an urban redevelopment TND has the same characteristics as the TND, the pricing model is unable to capture the pricing differential between new urbanist and conventional communities.

The sale price of houses in municipally subsidized projects may not reflect the true market value of the properties. If all units in a municipally developed TND are subsidized, the effect of the government subsidy may be difficult, if not impossible, to separate from other housing attributes, namely the new urbanist features.

Several TNDs are resort communities, where a portion of the residents in these TNDs are purchasing a second home or a vacation home. Resort communities generally offer a different set of amenities to residents and may attract a different clientele than year-round developments. Prices that consumers pay for a second home in a resort area may not be comparable to other developments that house year-round residents. Therefore, we also exclude resort TND communities. 
Six TNDs meet this series of qualitative tests, which include the most often cited new urbanist developments in the literature (except Seaside, which is a resort community): Kentlands, Harbor Town, Laguna West, Southern Village, Northwest Landing, and Celebration. We collect housing transaction data for the area around each of these TNDs and compare prices and housing characteristics of transactions in the TND with those in the surrounding area. After visiting each of the communities and reviewing the data, we decide to remove Harbor Town, Northwest Landing, and Celebration from the final analysis due to a lack of comparable transactions in the surrounding areas. 
Table 1 - Variable descriptions.

\begin{tabular}{|c|c|}
\hline Attribute & Description \\
\hline \multicolumn{2}{|c|}{ Dependent variables } \\
\hline PRICE & Sale price recorded on the deed \\
\hline LOGPRICE & Natural logarithm of sale price \\
\hline SFPRICE & Sale price per square foot of living area \\
\hline \multicolumn{2}{|c|}{ Site characteristics } \\
\hline LOT & Square footage of site \\
\hline LOGLOT & Natural logarithm of lot size \\
\hline PARKING & Number of covered or enclosed parking spaces \\
\hline \multicolumn{2}{|c|}{ Interior characteristics } \\
\hline$A R E A$ & $\begin{array}{l}\text { Square footage of living area, } \\
\text { excluding basement }\end{array}$ \\
\hline BATH & $\begin{array}{l}\text { Number of bathrooms, bathrooms with only a } \\
\text { sink and a toilet are counted as one-half }\end{array}$ \\
\hline BASEMENT & $\begin{array}{l}\text { Binary variable, } 1 \text {, if the house has a basement; } \\
0 \text {, otherwise }\end{array}$ \\
\hline FIREPLACE & Number of fireplaces \\
\hline$F L O O R^{\mathrm{a}}$ & Various binary variables \\
\hline \multicolumn{2}{|c|}{ Exterior characteristics } \\
\hline$R O O F^{b}$ & Various binary variables \\
\hline EXTWALL $L^{\mathrm{C}}$ & Various binary variables \\
\hline$H I P^{\mathrm{d}}$ & $\begin{array}{l}\text { Binary variable, } 1 \text {, if the house has a hip roof; } \\
0, \text { otherwise }\end{array}$ \\
\hline$S L A B^{\mathrm{e}}$ & $\begin{array}{l}\text { Binary variable, } 1 \text {, if the foundation of } \\
\text { improvement is slab; } 0 \text {, otherwise }\end{array}$ \\
\hline STORY $\mathrm{f}^{\mathrm{H}}$ & Various binary variables \\
\hline POOL & $\begin{array}{l}\text { Binary variable, } 1 \text { if the property has } \\
\text { a pool; } 0 \text {, otherwise }\end{array}$ \\
\hline
\end{tabular}


Table1 a continued

\begin{tabular}{ll}
\hline \hline Quality characteristics & \\
$G R A D E^{\mathrm{g}}$ & Various binary variables \\
$A G E$ & Property age in years \\
$A G E S Q U A R E$ & Age squared \\
Market characteristics & Various binary variables \\
$Y E A R^{\mathrm{h}}$ & Binary variable, 1, if the house is in a \\
$T N D$ & TND; 0, otherwise \\
& \\
\hline
\end{tabular}

${ }^{a}$ In Southern Village, floor materials are represented by two binary variables: HARDWOOD and TILE, with carpeted floor being the reference variable.

${ }^{\mathrm{b}}$ In Kentlands, roof materials are represented by WSHINGLE (equal to one if the house has wood shingle roof, or zero otherwise), with composite shingle being the reference variable. In Laguna West, roof materials are represented by COMPOSITE, with wood shake being the reference variable. In Southern Village, roof materials are represented by $M E T A L$, with composite shingle being the reference variable.

c In Kentlands, the materials of exterior wall are represented by ALUMINUM and BRICK, with frame being the reference group. In Laguna West, the materials are represented by $W O O D$, with stucco being the reference variable.

${ }^{\mathrm{d}}$ For roof types, the reference group is gable.

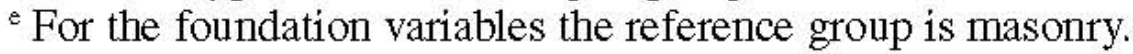

${ }^{\mathrm{f}}$ For the story binary variables the reference variable is two-story.

${ }^{g}$ Construction quality is represented by groups of binary variables. The reference group is $G R A D E 2$. In Maryland, the quality of construction materials is defined by the Maryland State Department of Assessment and Taxation (MSDAT). Quality of construction in the Laguna West market area is assigned by the Assessor's Office of Sacramento County, CA. In the Chapel Hill area, the quality indicator is defined by Orange County, NC.

${ }^{\mathrm{h}}$ The year of transaction is represented by YEAR95, YEAR96, and YEAR97, with 1994 being the reference year. 
Table 2 - Summary statistics.

\begin{tabular}{|c|c|c|c|c|c|c|}
\hline \multirow[b]{2}{*}{ Attribute } & \multicolumn{2}{|c|}{$\begin{array}{l}\text { Kentlands } \\
(n=1,546)\end{array}$} & \multicolumn{2}{|c|}{$\begin{array}{l}\text { Laguna West } \\
(n=3,301)\end{array}$} & \multicolumn{2}{|c|}{$\begin{array}{l}\text { Southern Village } \\
(n=503)\end{array}$} \\
\hline & Mean & Std. Dev. & Mean & Std. Dev. & Mean & Std. Dev. \\
\hline PRICE $(000)$ & 282.51 & 76.56 & 143.64 & 32.38 & 221.78 & 57.44 \\
\hline SFPRICE & 116.00 & 20.73 & 60.11 & 8.12 & 152.28 & 34.44 \\
\hline $\operatorname{LOT}(000)$ & 14.47 & 13.06 & 6.36 & 6.36 & 15.83 & 11.52 \\
\hline PARKING & 1.64 & 0.53 & 2.21 & 2.21 & 1.42 & 0.93 \\
\hline$A R E A(000)$ & 2.49 & 0.71 & 1.67 & 1.67 & 1.48 & 0.35 \\
\hline BATH & 2.77 & 0.58 & 2.32 & 2.32 & 2.51 & 0.42 \\
\hline BASEMENT & 0.87 & 0.33 & 1.00 & 0.00 & 0.89 & 0.28 \\
\hline FIREPLACE & 1.04 & 0.49 & 1.00 & 0.00 & 0.98 & 0.31 \\
\hline WSHINGLE & 0.20 & 0.40 & - & - & - & - \\
\hline COMPOSITE & - & - & 0.05 & 0.21 & - & - \\
\hline METAL & - & - & - & - & 0.02 & 0.15 \\
\hline$H I P$ & - & - & - & - & 0.18 & 0.39 \\
\hline ALUMINUM & 0.23 & 0.42 & - & - & - & - \\
\hline$B R I C K$ & 0.08 & 0.27 & - & - & - & - \\
\hline WOOD & - & - & 0.05 & 0.22 & - & - \\
\hline HARDWOOD & - & - & - & - & 0.40 & 0.49 \\
\hline TITLE & - & - & - & - & 0.01 & 0.13 \\
\hline$S L A B$ & - & - & - & - & 0.02 & 0.13 \\
\hline STORYI & 0.07 & 0.26 & 0.54 & 0.49 & 0.14 & 0.34 \\
\hline POOL & - & - & 0.05 & 0.22 & - & - \\
\hline LAKEVIEW & - & - & 0.03 & 0.19 & - & - \\
\hline GATED & - & - & 0.01 & 0.10 & - & - \\
\hline$G R A D E I$ & 0.02 & 0.15 & 0.01 & 0.07 & 0.07 & 0.27 \\
\hline GRADE3 & 0.43 & 0.49 & 0.13 & 0.34 & 0.54 & 0.49 \\
\hline GRADE4 & 0.03 & 0.18 & 0.01 & 0.06 & 0.02 & 0.15 \\
\hline$A G E$ & 10.10 & 8.70 & 2.46 & 3.43 & 6.57 & 12.78 \\
\hline YEAR95 & 0.25 & 0.43 & 0.23 & 0.42 & 0.33 & 0.47 \\
\hline$Y E A R 96$ & 0.21 & 0.40 & 0.29 & 0.45 & 0.34 & 0.47 \\
\hline YEAR97 & 0.22 & 0.41 & 0.16 & 0.37 & 0.13 & 0.34 \\
\hline$T N D$ & 0.10 & 0.31 & 0.09 & 0.29 & 0.16 & 0.36 \\
\hline
\end{tabular}


Table 3 a Comparison of housing attributes between TNDs and conventional suburban developments.

\begin{tabular}{|c|c|c|c|c|c|c|}
\hline \multirow[b]{2}{*}{ Attribute } & \multicolumn{2}{|l|}{ Kentlands } & \multicolumn{2}{|c|}{ Laguna West } & \multicolumn{2}{|c|}{ Southern Village } \\
\hline & $\begin{array}{l}\text { TND } \\
(n=170)\end{array}$ & $\begin{array}{l}\text { Conventional } \\
(n=1,376)\end{array}$ & $\begin{array}{l}\text { TND } \\
(n=326)\end{array}$ & $\begin{array}{l}\text { Conventional } \\
(n=2,975)\end{array}$ & $\begin{array}{l}\text { TND } \\
(n=82)\end{array}$ & $\begin{array}{l}\text { Conventional } \\
(n=421)\end{array}$ \\
\hline PRICE $(000)$ & 327.68 & 266.30 & 166.11 & 141.23 & 240.41 & 217.18 \\
\hline SFPRICE & 134.97 & 113.65 & 69.54 & 59.08 & 185.78 & 145.76 \\
\hline $\operatorname{LOT}(000)$ & 4.92 & 12.79 & 6.56 & 6.35 & 17.45 & 15.51 \\
\hline PARKING & 1.82 & 1.62 & 2.30 & 2.21 & 1.85 & 1.34 \\
\hline$A R E A(000)$ & 2.53 & 2.48 & 1.80 & 1.66 & 1.34 & 1.51 \\
\hline$B A T H$ & 2.93 & 2.75 & 2.46 & 2.31 & 2.58 & 2.49 \\
\hline BASEMENT & 0.73 & 0.89 & 0.00 & 0.00 & 0.03 & 0.10 \\
\hline FIREPLACE & 1.01 & 1.04 & 1.00 & 1.00 & 1.01 & 0.97 \\
\hline WSHINGLE & 0.94 & 0.11 & - & - & - & - \\
\hline COMPOSITE & - & - & 0.05 & 0.05 & - & - \\
\hline$M E T A L$ & - & - & - & - & 0.00 & 0.03 \\
\hline$H I P$ & - & - & - & - & 0.16 & 0.19 \\
\hline ALUMINUM & 0.11 & 0.24 & - & - & - & - \\
\hline$B R I C K$ & 0.13 & 0.07 & - & - & - & - \\
\hline WOOD & - & - & 0.00 & 0.06 & - & - \\
\hline HARDWOOD & - & - & - & - & 0.60 & 0.37 \\
\hline TITLE & - & - & - & - & 0.00 & 0.02 \\
\hline$S L A B$ & - & - & - & - & 0.00 & 0.02 \\
\hline STORYI & 0.01 & 0.08 & 0.44 & 0.54 & 0.02 & 0.17 \\
\hline$P O O L$ & - & - & 0.05 & - & - & - \\
\hline$L A K E V I E W$ & - & - & 0.29 & 0.01 & - & - \\
\hline GATED & - & - & 0.00 & 0.01 & - & - \\
\hline$G R A D E I$ & 0.00 & 0.02 & 0.00 & 0.01 & 0.01 & 0.09 \\
\hline GRADE3 & 0.70 & 0.39 & 0.37 & 0.11 & 0.69 & 0.51 \\
\hline GRADE4 & 0.17 & 0.01 & 0.03 & 0.00 & 0.00 & 0.03 \\
\hline$A G E$ & 0.85 & 11.24 & 0.65 & 2.67 & 2.51 & 7.36 \\
\hline YEAR95 & 0.22 & 0.25 & 0.25 & 0.24 & 0.32 & 0.34 \\
\hline YEAR96 & 0.10 & 0.22 & 0.33 & 0.29 & 0.46 & 0.32 \\
\hline YEAR97 & 0.11 & 0.23 & 0.14 & 0.17 & 0.21 & 0.12 \\
\hline
\end{tabular}


Table 4 a Estimation results of hedonic price models.

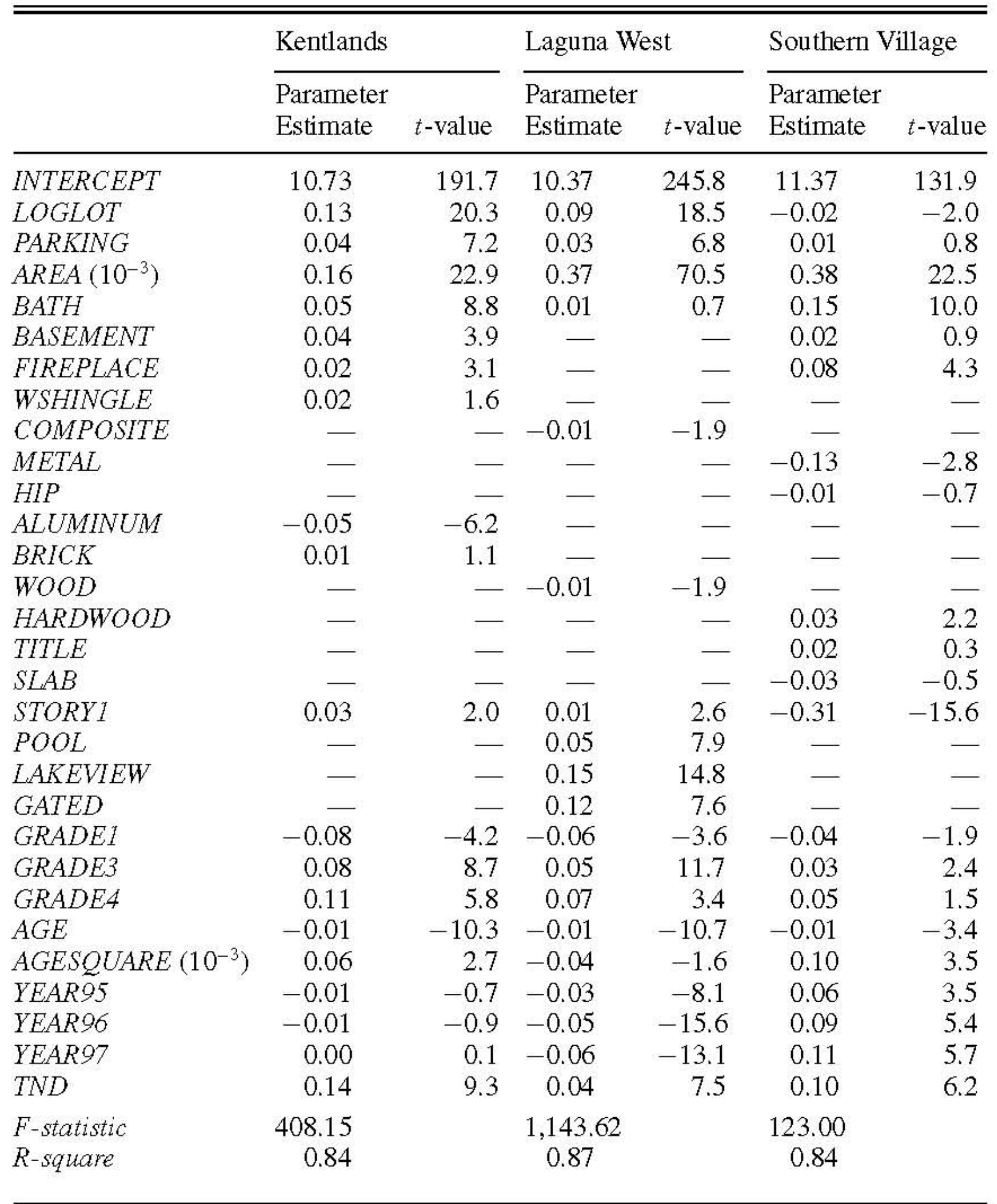


Table 5 a Price premium of new urbanist housing estimated with improvement age stratified data.

\begin{tabular}{|c|c|c|c|c|c|c|}
\hline \multirow[b]{3}{*}{ Age of House } & \multicolumn{2}{|l|}{ Kentlands } & \multicolumn{2}{|c|}{ Laguna West } & \multicolumn{2}{|c|}{ Southern Village } \\
\hline & Parameter & & Parameter & & Parameter & \\
\hline & Estimate & $t$-value & Estimate & $t$-value & Estimate & $t$-value \\
\hline New & 0.15 & 7.7 & 0.05 & 9.1 & 0.09 & 4.3 \\
\hline Less than 5 years & 0.16 & 10.7 & 0.04 & 8.3 & 0.09 & 5.6 \\
\hline Less than 10 years & 0.15 & 9.3 & 0.04 & 7.5 & 0.09 & 6.2 \\
\hline Less than 20 years & 0.14 & 9.0 & 0.04 & 7.5 & 0.09 & 6.2 \\
\hline All & 0.14 & 9.3 & 0.04 & 7.5 & 0.10 & 6.2 \\
\hline
\end{tabular}


Table 6 - Stacked regression results.

\begin{tabular}{|c|c|c|c|c|c|c|c|c|}
\hline & \multirow{2}{*}{\multicolumn{2}{|c|}{ Specification 1}} & \multicolumn{6}{|c|}{ Specification 2} \\
\hline & & & \multicolumn{2}{|c|}{ Original Term } & \multicolumn{2}{|c|}{ Interactive $\operatorname{Term}(\times M D)$} & \multicolumn{2}{|c|}{ Interactive $\operatorname{Term}(\times N C)$} \\
\hline & $\begin{array}{l}\text { Parameter } \\
\text { Estimate }\end{array}$ & $t$-value & $\begin{array}{l}\text { Parameter } \\
\text { Estimate }\end{array}$ & $t$-value & $\begin{array}{l}\text { Parameter } \\
\text { Estimate }\end{array}$ & $t$-value & $\begin{array}{l}\text { Parameter } \\
\text { Estimate }\end{array}$ & $t$-value \\
\hline INTERCEPT & 10.36 & 301.6 & 10.21 & 163.9 & 0.06 & 7.6 & 1.12 & 12.0 \\
\hline LOGLOT & 0.10 & 22.7 & 0.10 & 13.3 & 0.03 & 2.9 & -0.11 & -10.5 \\
\hline PARKING & 0.05 & 13.0 & 0.02 & 4.6 & 0.02 & 2.6 & -0.01 & -1.7 \\
\hline$A R E A$ & 0.26 & 57.6 & 0.40 & 50.3 & -0.24 & -23.9 & -0.00 & -0.2 \\
\hline BATH & 0.06 & 11.8 & 0.02 & 1.6 & 0.03 & 3.0 & 0.14 & 8.5 \\
\hline BASEMENT & 0.05 & 5.6 & 0.04 & 2.2 & 0.01 & 0.7 & - & - \\
\hline FIREPLACE & 0.02 & 2.9 & 0.08 & 5.4 & -0.05 & -3.1 & - & - \\
\hline STORYI & -0.01 & -2.6 & 0.02 & 2.9 & 0.00 & 0.0 & -0.33 & -18.1 \\
\hline GRADEI & -0.08 & -5.9 & -0.07 & -0.9 & 0.01 & 0.0 & 0.03 & 0.3 \\
\hline GRADE3 & 0.04 & 6.5 & 0.01 & 0.8 & 0.07 & 6.0 & 0.04 & 3.1 \\
\hline GRADE4 & 0.05 & 2.9 & 0.02 & 0.3 & 0.10 & 1.8 & 0.06 & 1.0 \\
\hline$A G E$ & -0.01 & -10.9 & -0.00 & -3.8 & -0.01 & -5.0 & 0.00 & 0.8 \\
\hline AGESQUARE & 0.06 & 4.6 & -0.15 & -3.2 & 0.21 & 3.9 & 0.19 & 3.6 \\
\hline$Y E A R 95$ & -0.01 & -3.2 & -0.03 & -6.1 & 0.02 & 2.7 & 0.09 & 6.6 \\
\hline YEAR96 & -0.03 & -6.5 & -0.06 & -12.7 & 0.06 & 6.1 & 0.15 & 10.5 \\
\hline YEAR97 & -0.03 & -5.7 & -0.07 & -11.3 & 0.07 & 7.5 & 0.18 & 10.4 \\
\hline$M D$ & 0.45 & 31.4 & 0.58 & 7.6 & - & - & - & - \\
\hline$N C$ & 0.45 & 42.5 & 1.12 & 12.0 & - & - & - & - \\
\hline$M A G E$ & -0.01 & -6.4 & -0.01 & -5.8 & - & - & - & - \\
\hline$T N D$ & 0.08 & 8.9 & 0.07 & 9.6 & - & - & - & - \\
\hline
\end{tabular}

Tu, Eppli 19 
Table 7 . Decomposition analysis of price differentials between new urbanist and conventional developments.

\begin{tabular}{lcll}
\hline \hline & Kentlands & Laguna West & Southern Village \\
\hline Price effect & 0.37 & 0.08 & 0.07 \\
Characteristic effect & -0.16 & 0.09 & 0.06 \\
Total & 0.21 & 0.17 & 0.13 \\
& & & \\
\hline
\end{tabular}


Table 8 Analysis of the price effect.

\begin{tabular}{|c|c|c|c|c|c|c|}
\hline & \multicolumn{2}{|c|}{ Kentlands } & \multicolumn{2}{|c|}{ Laguna West } & \multicolumn{2}{|c|}{ Southern Village } \\
\hline & $\overline{\Delta \beta_{i}}$ & $x^{*} \cdot \Delta \beta_{i}$ & $\overline{\Delta \beta_{i}}$ & $x^{*} \cdot \Delta \beta_{i}$ & $\Delta \beta_{i}$ & $x^{*} \cdot \Delta \beta_{i}$ \\
\hline INTERCEPT & -0.27 & -0.27 & 0.16 & 0.16 & 0.59 & 0.59 \\
\hline LOT & 0.07 & 0.64 & -0.00 & -0.02 & -0.01 & -0.05 \\
\hline PARKING & -0.04 & -0.07 & -0.04 & -0.08 & -0.00 & -0.01 \\
\hline$A R E A(000)$ & 0.04 & 0.11 & 0.00 & -0.02 & -0.00 & -0.24 \\
\hline$B A T H$ & -0.03 & -0.09 & 0.01 & 0.02 & -0.00 & -0.01 \\
\hline BASEMENT & -0.08 & -0.06 & - & - & 0.04 & 0.00 \\
\hline FIREPLACE & -0.03 & -0.03 & - & 一 & -0.08 & -0.08 \\
\hline WSHINGLE & -0.07 & -0.04 & - & - & - & - \\
\hline COMPOSITE & - & - & -0.04 & -0.00 & - & - \\
\hline METAL & - & - & - & - & 0.12 & 0.00 \\
\hline$H I P$ & - & 一 & 一 & - & 0.01 & 0.00 \\
\hline ALUMINUM & 0.08 & 0.01 & - & - & - & - \\
\hline$B R I C K$ & 0.04 & 0.00 & - & - & - & - \\
\hline WOOD & - & - & -0.06 & -0.00 & - & - \\
\hline HARDWOOD & - & - & - & - & 0.01 & 0.00 \\
\hline TITLE & - & - & - & - & -0.02 & -0.00 \\
\hline$S L A B$ & - & - & - & - & 0.02 & 0.00 \\
\hline STORYI & -0.17 & -0.07 & 0.01 & 0.00 & 0.23 & 0.02 \\
\hline POOL & - & - & -0.02 & -0.00 & - & - \\
\hline LAKEVIEW & - & - & 0.13 & 0.02 & - & - \\
\hline GATED & - & - & -0.27 & -0.00 & - & - \\
\hline$G R A D E I$ & 0.08 & 0.00 & 0.04 & 0.00 & -0.11 & -0.01 \\
\hline GRADE3 & -0.04 & -0.02 & 0.01 & 0.00 & -0.05 & -0.03 \\
\hline GRADE4 & -0.02 & -0.00 & 0.15 & 0.00 & -0.06 & -0.00 \\
\hline$A G E$ & 0.03 & 0.17 & 0.01 & 0.02 & 0.00 & 0.01 \\
\hline AGESQUARE & 0.00 & 0.03 & 0.00 & 0.01 & -0.00 & -0.05 \\
\hline YEAR 95 & 0.04 & 0.01 & -0.02 & -0.01 & -0.12 & -0.04 \\
\hline YEAR96 & -0.01 & -0.00 & -0.04 & -0.01 & -0.07 & -0.03 \\
\hline$Y E A R 97$ & -0.04 & -0.01 & -0.08 & -0.01 & -0.11 & -0.02 \\
\hline Net Price Effect & & 0.37 & & 0.08 & & 0.07 \\
\hline
\end{tabular}

